\title{
Biodiesel Production from Rubber Seed Oil Using Natural Zeolite Supported Metal Oxide Catalysts
}

\author{
Ahmad Nasir Pulungan*, Agus Kembaren, Nurfajriani Nurfajriani, \\ Feri Andi Syuhada, Junifa Layla Sihombing, Muhammad Yusuf, Rahayu Rahayu \\ Department of Chemistry, Faculty of Mathematics and Natural Sciences, Universitas Negeri Medan, \\ Jl. Willem Iskandar Pasar V Medan Estate, Medan 20221, Indonesia
}

Received: 26 January 2021

Accepted: 8 April 2021

\begin{abstract}
The conversion of biodiesel from rubber seed oil has been carried out using heterogeneous catalyst based on natural zeolite. The methods used include activated and calcined to produce active natural zeolite (ZAA). ZAA are embodied metal oxides of $\mathrm{PbO}, \mathrm{ZnO}$, and $\mathrm{ZrO}_{2}$ through wet impregnation to produce bifunctional catalyst. The catalysts activity test was carried out in biodiesel synthesis at temperature $60^{\circ} \mathrm{C}$ for 60 minutes with $5 \%(\mathrm{w} / \mathrm{w})$ catalysts. Crystallinity of catalysts increased after the activation process and $\mathrm{ZrO}_{2}$ loaded but decreased after $\mathrm{PbO}$ and $\mathrm{ZnO}$ loaded. The catalyst components after modification decreased Al levels due to dealumination process as well as reduced impurities. Spesific surface area of catalysts decreased after impregnation while total pore volume increased. Metal oxides loaded has an effect in increasing biodiesel conversion and reducing FFA content. The best performance was shown by $\mathrm{ZrO}_{2} / \mathrm{ZAA}$ catalysts with yield conversion of $58.10 \%$ and FFA conversion to methyl ester reaches $86.22 \%$. The characteristics of water content, FFA content, and density of $0.092 \%$, $1.081 \%$, and $0.880 \mathrm{~g} / \mathrm{cm}^{3}$, respectively. These data showed that biodiesel from rubber seed oil which was catalyzed by a bifunctional catalyst has the potential to be developed as an alternative source of future renewable and environmentally friendly fuels.
\end{abstract}

Keywords: natural zeolite, biodiesel, rubber seed oil, bifunctional catalyst, metal oxides

\section{Introduction}

Rubber seeds are the waste products of rubber plantations which are abundant in availability but have not been fully utilized. Rubber seed production in Indonesia currently reach 5 million tons per year, with oil content of $40-50 \%$ can produce rubber seed

*e-mail: nasirpl@unimed.ac.id oil of 2 million tons per year [1]. Therefore, rubber seed oil has the potential to be developed as a raw material for biodiesel and this process directly reduces environmental waste. However, the main obstacle in the use of rubber seed oil as a raw material in the process of making biodiesel is the high free fatty acid (FFA) content of 5-40\%. Conventionally, biodiesel production is by reacting vegetable oil with alcohol using an alkaline catalyst. However, alkaline catalysts only work well in oils with low FFA levels $<0.5 \%$ and in water-free conditions. For vegetable oils with a high 
FFA content, the use of alkaline catalysts can cause a saponification reaction thereby reducing the yield of biodiesel produced.

Research related to the manufacture of biodiesel from rubber seed oil has been carried out with various methods including conventional methods with homogeneous catalysts, supercritical methanol, In situ transesterification and Ultrasound assisted [2-4]. However, the problems that arise are almost the same, including difficulty in the separation process, corrosion problems and the impact of environmental pollution. Moreover, the supercritical method must be carried out at high temperature and pressure so that the process costs are more expensive for tool maintenance [5]. Heterogeneous acid catalysts or solid acid catalysts can be used as a solution in making biodiesel from oil with high FFA content because of their reusability and regeneration, easy separation process, higher reaction rate and selectivity, low cost, less energy requirements, and environmentally friendly [6,7]. The use of a heterogeneous acid catalyst will not produce soap through the neutralization reaction of free fatty acids or saponification of triglycerides. In addition, by using a heterogeneous acid catalyst the FFA esterification process and triglyceride transesterification can be carried out in one reaction stage so as to reduce production costs [8]. Some of these catalysts are zeolite [9], silica [10] alumina [11], nafion [12], MCM-41 [13], amberlyst-15 [14], and sulfate zirconia [15] are catalysts that can be used in the process of making biodiesel [16]. This catalyst has been used for esterification and transesterification of some vegetable oils. In general, the use of solid acid catalysts shows good performance for the esterification reaction even in vegetable oils with high FFA content. However, basic catalysts such as metal oxides still show higher performance or activity than solid acid catalysts [17]. Several types of solid oxide catalysts that have been used include $\mathrm{CaO}$ [18], $\mathrm{MgO}$ [19], $\mathrm{SrO}$ [20], $\mathrm{ZnO}$ [21], $\mathrm{PbO}$ [22], and zirconium oxide [23]. Therefore, a combination of a solid acid catalyst such as zeolite coupled with metal oxides will provide a higher conversion of biodiesel products at lower relative temperatures [24]. Heterogeneous catalysts that have both acid and oxide sites can perform esterification of FFA and transesterification of triglycerides simultaneously to produce biodiesel [25]. In addition, zeolite with a higher acidity than silica and alumina produces a stronger interaction with metal oxides so that the catalyst is more stable.

Based on that, this research develop the process of making biodiesel from rubber seed oil using a solid acid catalyst (heterogeneous) based on natural zeolite which is very abundant in Indonesia. Before being used as a natural zeolite catalyst, activation will be carried out to increase its catalytic activity by chemical and physical methods and modification of its acidity by developing $\mathrm{ZrO}_{2}, \mathrm{ZnO}$, and $\mathrm{PbO}$ metal oxides. The resulting catalysts are expecting to act as a bifunctional catalysts that play the role in the FFA esterification process and triglyceride transesterification at the same time so as to increase the quantity and quality of biodiesel. In addition, reusable heterogenous catalysts can reduce production costs as well as environmental toxicity. Biodiesel produced from rubber seed oil with heterogeneous catalysts is expected to act as an alternative fuel to substitute for fossil fuels or be part of sustainable energy in the future, thereby reducing the problem of limited resources and environmental pollution.

\section{Material and Methods}

\section{Materials}

The materials used in this study were: distilled water, aquabidest, natural zeolite, $\mathrm{ZrCl}_{4}$ (pa Merck), zinc-nitrate and $\mathrm{Pb}$-nitrate (pa Merck), $\mathrm{HCl}$ (pa Merck), nitrogen gas, oxygen gas (PTAneka Gas Indonesia), Rubber Seed, N-Hexane (technical), Methanol (pa Merck)., $\mathrm{NaOH}$ (pa Merck), $\mathrm{AgNO}_{3}$ (pa Merck), Ethanol 96\%, Indicator PP.

\section{Preparation of Rubber Seed Oil}

The process of extracting oil from rubber seeds in this study was carried out by an extraction process. Previously, the preparation of rubber seed samples had been carried out including the steps 1) separating the rubber shells and seeds, 2) drying the rubber seeds in the sun, then 3) manually reducing the size of the rubber seeds, then taking the rubber seed oil using the extraction method in soxhletation using n-hexane solvent.

\section{Preparation and Activation of Natural Zeolite}

The preparation and activation of natural zeolite in this study followed the procedure reported by Sihombing et al. [26] In the early stages, natural zeolite was crushed and sieved to obtain zeolite with a size of 100 mesh. This natural zeolite was then washed by soaking in distilled water for 24 hours at room temperature. Then the zeolite was filtered and the clean precipitate was dried at a temperature of $100^{\circ} \mathrm{C}$ to obtain a clean natural zeolite (ZB) sample. The ZB sample was chemically activated with $3 \mathrm{M} \mathrm{HCl}$, refluxed at $90^{\circ} \mathrm{C}$ for 30 minutes then filtered, the resulting sediment was washed with aquadest until the $\mathrm{pH}$ was neutral, the precipitate was oven at $120^{\circ} \mathrm{C}$ to dry for 3 hours, followed by calcined at $500^{\circ} \mathrm{C}$ with nitrogen gas flow to obtain acid-activated natural zeolite (ZAA).

$$
\begin{aligned}
& \text { Synthesis of } \mathrm{ZrO}_{2} / \mathrm{ZAA}, \mathrm{ZnO} / \mathrm{ZAA}, \\
& \text { and } \mathrm{PbO} / \mathrm{ZAA} \text { Catalysts }
\end{aligned}
$$

Synthesis of $\mathrm{ZrO}_{2} / \mathrm{ZAA}, \mathrm{ZnO} / \mathrm{ZAA}$, and $\mathrm{PbO} / \mathrm{ZAA}$ catalysts was was done by wet impregnation method. At the initial stage, a metal precursor solution and ZAA 
was made with a certain ratio. Then the two solutions were mixed into a three neck flask and reflux was carried out at $90^{\circ} \mathrm{C}$ for 4 hours, followed by the filtering process. The precipitate obtained was dried at $130^{\circ} \mathrm{C}$ followed by a calsination process at $500^{\circ} \mathrm{C}$ for 1 hour with Nitrogen gas flow, then oxidized at the same temperature with oxygen gas flow for 1 hour to obtain $\mathrm{ZrO}_{2} / \mathrm{ZAA}$ catalyst. The same procedure was carried out for the preparation of $\mathrm{ZnO} / \mathrm{ZAA}$, and $\mathrm{PbO} / \mathrm{ZAA}$ catalysts. Some of the important physical and chemical characteristics of $\mathrm{ZrO}_{2} / \mathrm{ZAA}, \mathrm{ZnO} / \mathrm{ZAA}$, and $\mathrm{PbO} / \mathrm{ZAA}$ catalysts were characterized using: XRD, SEM, EDX and nitrogen gas sorption analysis with BET method.

\section{Conversion of Rubber Seed Oil into Biodiesel}

The conversion process of rubber seed oil into biodiesel fuel fraction was carried out by mixing $99 \%$ methanol and 5\% ZAA catalyst in an erlenmeyer flask. The mixture was added to the rubber seed oil with an oil:methanol ratio of 1:6. Then heated at $60^{\circ} \mathrm{C}$ with a stirring speed of $600 \mathrm{rpm}$ for 1 hour. The resulting reaction mixture was separated from the catalyst using filter paper and a Buechner funnel. The mixture which had been free from the catalyst was then decanted for 2 days to separate the resulting biodiesel product. Decantation was carried out using a separating funnel. The mixture was washed with hot aquadest until the washing water was clear and methyl ester layer can be seen at the top. The same was done for the $\mathrm{ZrO}_{2} / \mathrm{ZAA}$, $\mathrm{ZnO} / \mathrm{ZAA}$, and $\mathrm{PbO} / \mathrm{ZAA}$ catalysts. The optimum biodiesel produced was then tested for its physical and chemical properties. Some of the important physical and chemical properties that determine the quality of the biodiesel products produced include: density, moisture content, FFA content, and analysis of fatty acid and methyl ester content by GC-MS.

\section{Results and Discussion}

\section{Cristallinity Analysis}

Testing the properties of zeolite crystals was carried out by using X-Ray Diffractometer (XRD). The characteristic zeolite peaks were observed in the region $2 \theta=18-30^{\circ}$. The comparison of zeolite spectra after

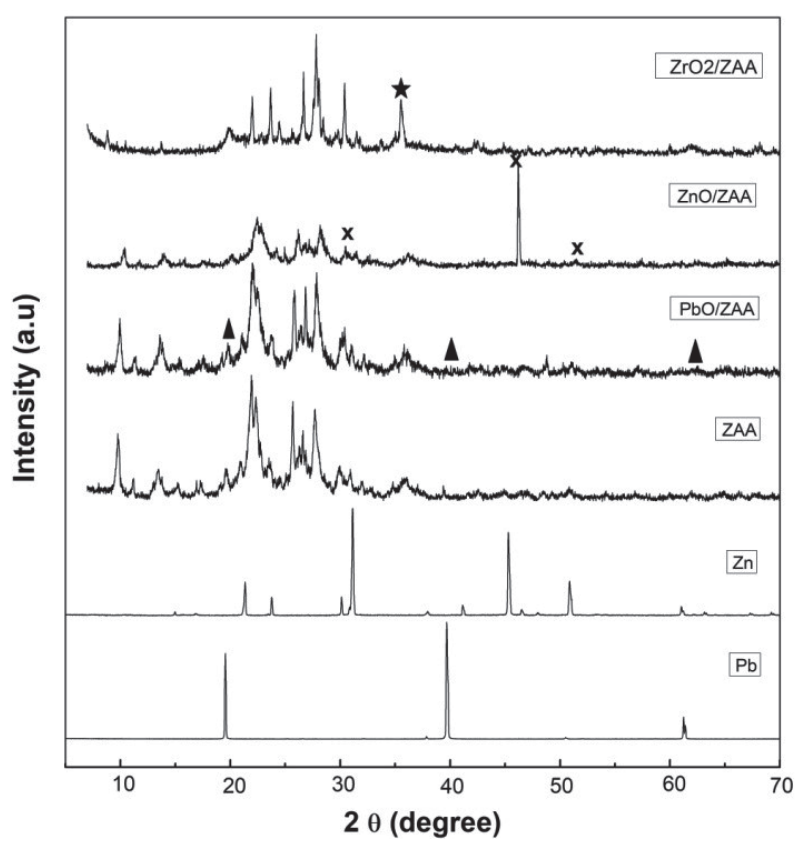

Fig. 1. XRD diffractogram comparison of ZAA, PbO/ZAA, $\mathrm{ZnO} / \mathrm{ZAA}, \mathrm{ZrO}_{2} / \mathrm{ZAA}, \mathrm{Pb}$, and $\mathrm{Zn}$.

acid activation and after metal oxide loading can be observed in Fig. 1.

Based on Fig. 1, it is known that in general the peaks that appear on the diffractogram are not much different from one another. It can be said that the acid treatment, calcination, and impregnation process did not change the zeolite structure. However, there was a change in intensity at several main peaks summarized in Table 1. In addition, new peaks appeared which were characteristic peaks for metal in the region $2 \theta=46.199^{\circ}$; $31.290^{\circ}$; $50.947^{\circ}$ for $\mathrm{Zn}, 19.780^{\circ}$ and $60.020^{\circ}$ for $\mathrm{Pb}$, and $35.646^{\circ}$ for $\mathrm{Zr}$. This is supported by the XRD test data carried out for $\mathrm{Zn}$ metal showing a characteristic main peak in the area of $45.219^{\circ}(\mathrm{d}=2.000 \AA), 31.113^{\circ}$ $(\mathrm{d}=2.872 \AA)$, and $50.865^{\circ}(\mathrm{d}=1.793 \AA)$. $\mathrm{Pb}$ metal showing a characteristic main peak in the area of $19.540^{\circ}(\mathrm{d}=4.539 \AA)$ dan $61.235^{\circ}(\mathrm{d}=1.512 \AA)$. Meanwhile for $\mathrm{Pb}$ did not show significant characteristic peaks with high intensity because of its amount is slightly dispersed in the zeolite. The presence of $\mathrm{Pb}$ metal, $\mathrm{Zn}$, and $\mathrm{Zr}$ are supported by chemical composition of catalyst in Table 2 .

Table 1. Intensity of the main zeolite peaks and crystal sizes of the catalysts.

\begin{tabular}{|c|c|c|c|c|c|c|c|c|}
\hline \multirow{2}{*}{$2 \theta\left({ }^{\circ}\right)$} & \multicolumn{2}{|c|}{$\mathrm{ZAA}$} & \multicolumn{2}{c|}{$\mathrm{PbO} / \mathrm{ZAA}$} & \multicolumn{2}{c|}{$\mathrm{ZnO} / \mathrm{ZAA}$} & \multicolumn{2}{c|}{$\mathrm{ZrO}_{2} / \mathrm{ZAA}$} \\
\cline { 2 - 10 } & Intensity & $\mathrm{D}(\mathrm{nm})$ & Intensity & $\mathrm{D}(\mathrm{nm})$ & Intensity & $\mathrm{D}(\mathrm{nm})$ & Intensity & $\mathrm{D}(\mathrm{nm})$ \\
\hline 22.1007 & 284 & 7.154 & 168 & 7.297 & 76 & 7.892 & 233 & 6.797 \\
\hline 25.7400 & 148 & 8.480 & 85 & 7.950 & 39 & 31.656 & 124 & 8.258 \\
\hline 26.5200 & 122 & 11.911 & 80 & 11.760 & 50 & 47.322 & 84 & 11.365 \\
\hline 27.7228 & 193 & 10.278 & 127 & 11.554 & 63 & 52.921 & 157 & 13.007 \\
\hline
\end{tabular}


Table 2. Characteristics of catalysts.

\begin{tabular}{|c|c|c|c|c|}
\hline \multirow{2}{*}{ Characteristics } & \multicolumn{4}{|c|}{ Catalyst } \\
\hline & ZAA & $\mathrm{PbO} / \mathrm{ZAA}$ & $\mathrm{ZnO} / \mathrm{ZAA}$ & $\mathrm{ZrO}_{2} / \mathrm{ZAA}$ \\
\hline Cristallinity (\%) & 76.739 & 66.790 & 41.080 & 77.117 \\
\hline Surface area $\left(\mathrm{m}^{2} / \mathrm{g}\right)$ & 28.812 & 18.469 & 23.317 & 27.570 \\
\hline Total pore volume $(\mathrm{cc} / \mathrm{g})$ & 0.074 & 0.078 & 0.093 & 0.095 \\
\hline Pore radius (nm) & 1.7172 & 5.3021 & 1.5685 & 1.6750 \\
\hline \multicolumn{5}{|l|}{ Composition (\%) } \\
\hline $\mathrm{O}$ & 51.34 & 71.39 & 72.12 & 62.34 \\
\hline $\mathrm{Si}$ & 28.89 & 22.72 & 20.87 & 29.64 \\
\hline $\mathrm{Al}$ & 2.03 & 3.65 & 4.02 & 3.55 \\
\hline $\mathrm{Pb}$ & - & 0.12 & - & _ \\
\hline $\mathrm{Zn}$ & - & - & 0.18 & _ \\
\hline $\mathrm{Zr}$ & - & - & - & 1.63 \\
\hline Impurities & 1.74 & 2.11 & 2.83 & 2.92 \\
\hline
\end{tabular}

The intensity of some of the main peaks tended to decrease after acid treatment. Hydrochloric acid causes the release of aluminum species which is outside and within the zeolite framework. Other metals that can dissolve in $\mathrm{HCl}$ also come out with aluminum [27]. The same thing happened to zeolites after calcination and oxidation. The peak intensity decreased, presumably because the crystalline water trapped in the framework managed to escape resulting in open zeolit pores. Zeolite carried by metal oxide $\mathrm{ZrO}_{2}$ tends to be more able to maintain the structure of the framework, hence the decrease in peak intensity occurs less. In contrast, $\mathrm{ZnO} / \mathrm{ZAA}$ catalyst is more brittle and easily damaged in framework structure that the intensity changes are greater. This difference can be observed further based on the nature of the crystals formed. The determination crystal size was obtained from the calculation using the Debye-Scherrer equation from the X-Ray Diffraction data that can be seen in Tables 1 .

Based on the data of zeolite crystallinity in Table 2, it is known that $\mathrm{ZrO}_{2} / \mathrm{ZAA}$ catalyst has the highest crystallinity and has increased after impregnation and oxidation processes. This increase was presumably due to the metal being carried out giving rise to new characteristic peaks with a high intensity that affects the crystallinity of the catalyst. This indicates that the $\mathrm{ZrO}_{2}$ metal oxide carried is distributed on the zeolite surface. Meanwhile, the decrease in crystallinity in $\mathrm{PbO} / \mathrm{ZAA}$ and $\mathrm{ZnO} / \mathrm{ZAA}$ is thought to have occurred due to the metal dispersion process covering the zeolite pores.

Crystal size data show that the $\mathrm{ZrO}_{2} / \mathrm{ZAA}$ and $\mathrm{PbO} /$ ZAA catalysts have a shape that is not much different from the acid-activated zeolite with a range of 6-13 $\mathrm{nm}$. Meanwhile, for $\mathrm{ZnO} / \mathrm{ZAA}$ catalyst the crystal size increased significantly with a size range of 7-52 nm.
This increase in crystal size indicates that the $\mathrm{ZnO} /$ ZAA catalyst experiences coagulation or sintering. The crystal grain size can be observed more clearly than the surface morphological image of the zeolite using SEM analysis in Fig. 2.

\section{Morphological Analysis}

Characterization using SEM was carried out to see the surface morphological structure, grain size, structural defects, and contamination composition of a material. The SEM data obtained information on the surface morphology and metal dispersion of the zeolite, while the EDS obtained the chemical composition on the surface of the sample. Fig. 2 shows the surface morphology of the $\mathrm{ZAA}, \mathrm{PbO} / \mathrm{ZAA}, \mathrm{ZnO} / \mathrm{ZAA}$ and $\mathrm{ZrO}_{2} / \mathrm{ZAA}$ catalysts with a magnification of 1000 times. In Fig. 2a), the surface micrograph of ZAA shows that the surface structure consists of lamellars with small sizes and there are still lumps. After the metal oxide impregnation process, there was a change in the surface morphology of the zeolite. In $\mathrm{PbO} / \mathrm{ZAA}$ and $\mathrm{ZnO} / \mathrm{ZAA}$ catalysts, the grain size of zeolite became larger than that of activated zeolite, especially in $\mathrm{ZnO} / \mathrm{ZAA}$ the surface morphology was more heterogeneous. This is in accordance with the crystal size calculations in Table 1 which shows the crystal size of $\mathrm{ZnO} / \mathrm{ZAA}$ is the largest compared to other zeolites. Meanwhile, $\mathrm{ZrO}_{2} / \mathrm{ZAA}$ in Fig. 2d) shows a smoother and more homogeneous surface structure. This data supports XRD data which shows the metal dispersing process does not occur sintering. The metal oxide is succesfully distributed on the zeolite surface.

The chemical composition of zeolites can be determined by EDS analysis which is shown in graphical form in Fig. 2. The percentage composition of 

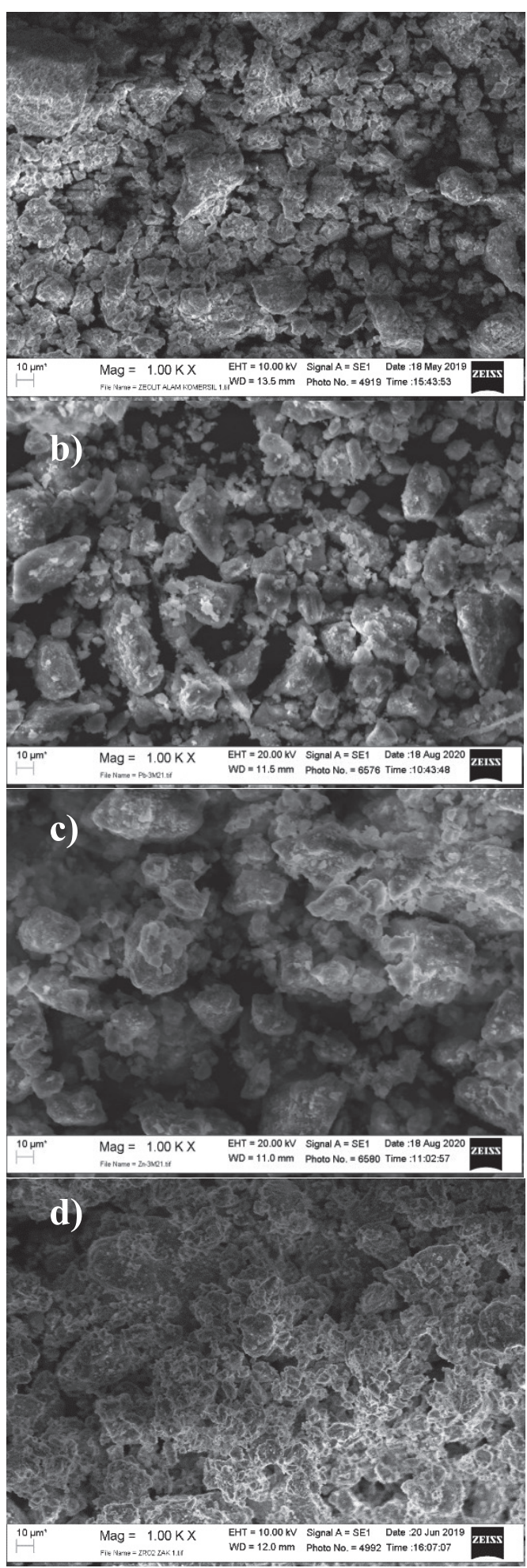
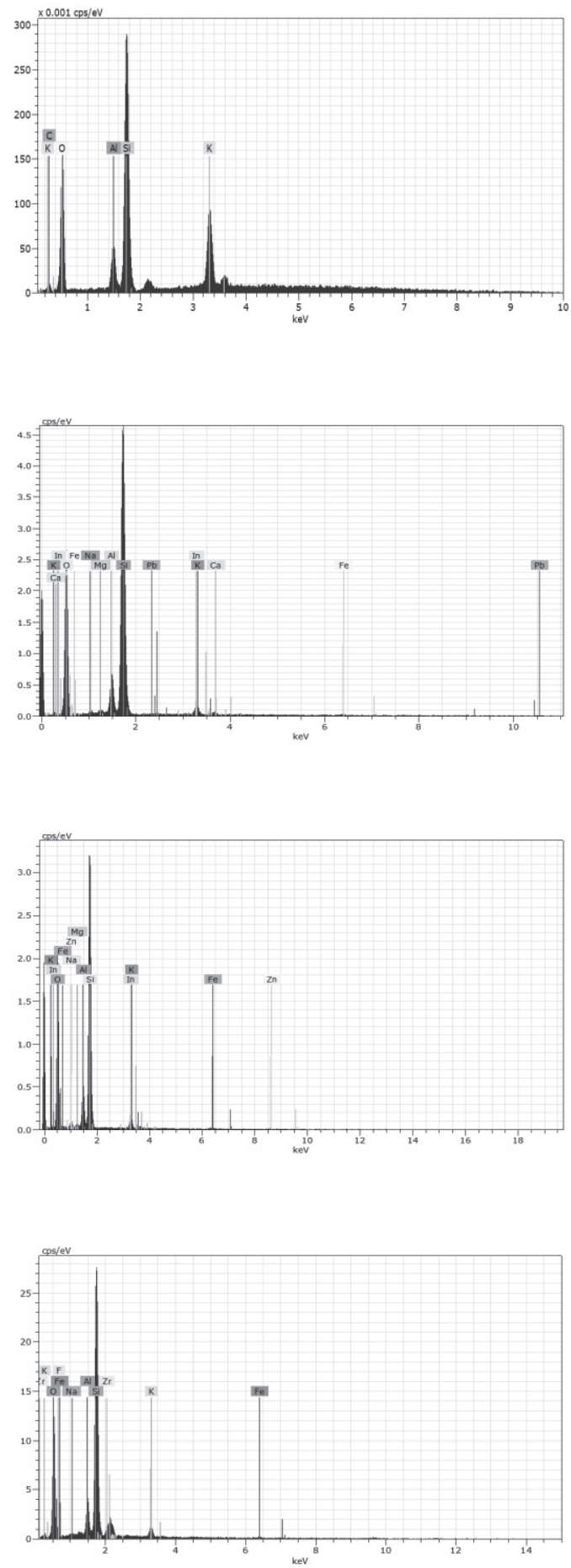

Fig. 2. Morphological structure and chemical composition of catalysts a) $\mathrm{ZAA}$; b) $\mathrm{PbO} / \mathrm{ZAA}$; c) $\mathrm{ZnO} / \mathrm{ZAA}$; and d) $\mathrm{ZrO}_{2} / \mathrm{ZAA}$.

the zeolite components is summarized in Table 2. Based on the EDS data, it can be seen that the percentage of metal that has been successfully carried from the $1 \%$ metal impregnation treatment. Only $0.12 \%$ and $0.18 \%$ carry $\mathrm{Pb}$ and $\mathrm{Zn}$ respectively, while $\mathrm{Zr}$ is carried more than $1 \%$. In addition, other impurity elements have decreased after impregnation and oxidation processes so that the modified zeolite becomes cleaner. In this case the calcination and oxidation processes play an important role in removing alkaline metal impurities such as $\mathrm{K}, \mathrm{Ca}, \mathrm{Mg}, \mathrm{Na}$, and evaporating crystalline water and $\mathrm{CO}_{2}$ from the zeolite framework so as to increase the catalytic activity of the catalyst. The calcination process with high temperature as a thermal activation changes metal hydroxides into active metal oxides on the catalyst [28]. 


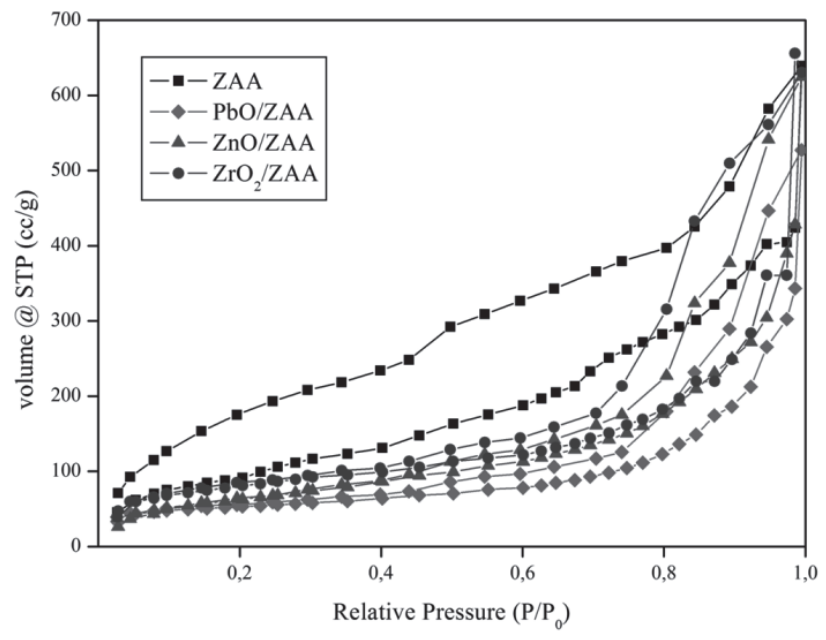

Fig. 3. Comparison of $\mathrm{N}_{2}$ gas adsorption-desorption isotherm on ZAA, $\mathrm{PbO} / \mathrm{ZAA}, \mathrm{ZnO} / \mathrm{ZAA}$, and $\mathrm{ZrO}_{2} / \mathrm{ZAA}$ catalyst.

\section{$\mathrm{N}_{2}$ Gas Sorption Analysis}

BET analysis provides a graph form of the adsorptiondesorption isotherm of $\mathrm{N}_{2}$ gas at ZAA, $\mathrm{PbO} / \mathrm{ZAA}$, $\mathrm{ZnO} / \mathrm{ZAA}, \mathrm{ZrO}_{2} / \mathrm{ZAA}$ as shown in Fig. 3. The graph shows the existence of loop hysterysis at a relative pressure of $0.4-0.9$ so it is classified as a type IV in accordance with the IUPAC classification. The existence of loop hysterysis and high graph increase in $\mathrm{P} / \mathrm{Po}$ characterize that $\mathrm{ZAA}, \mathrm{PbO} / \mathrm{ZAA}, \mathrm{ZnO} / \mathrm{ZAA}$, $\mathrm{ZrO}_{2} / \mathrm{ZAA}$ have mesoporous and micropores in their structure [29].

Based on the data in Table 2, it is known that the specific surface area of the catalyst generally decreases after the impregnation process of $\mathrm{Pb}, \mathrm{Zn}$, and $\mathrm{Zr}$ metals. The total pore volume is in the range of $0.07-0.09$ $\mathrm{cc} / \mathrm{g}$. Meanwhile, the mean pore radius of the ZAA, $\mathrm{ZnO} / \mathrm{ZAA}, \mathrm{PbO} / \mathrm{ZAA}$, and $\mathrm{ZrO}_{2} / \mathrm{ZAA}$ show that the catalysts are mesoporous material (pore diameter $2-50 \mathrm{~nm})$. The total pore volume increases after metal loaded. Song et al. (2013) [30] reported that metal support layer can increase the pore volume of the molecular sieve that can improve the selectivity of catalysts. Metal loading is indicated to block some micropores, causing a decrease in the surface area [31]. The highest reduction in surface area occurred in $\mathrm{PbO} / \mathrm{ZAA}$ catalysts up to $35.89 \%$, but at the same time new mesopores were formed on the $\mathrm{PbO} / \mathrm{ZAA}$ catalyst due to the superposition of the metal layer on the zeolite surface.

\section{Catalyst Activity Test in Biodiesel Synthesis}

Rubber seed oil that has been obtained from the extraction process with n-hexane solvent is then synthesized into biodiesel with an oil: methanol ratio of $1: 6,5 \%$ catalyst (w/w oil), and the process conditions at $60^{\circ} \mathrm{C}$ for 1 hour. The test results for the characteristics of rubber seed oil and biodiesel are summarized in Table 3.

The comparison of the amount of biodiesel yield conversion can be observed in Fig. 4. Biodiesel synthesized using $\mathrm{ZrO}_{2} / \mathrm{ZAA}$ catalysts has the highest yield with the highest percentage reaching $58.10 \%$. The water content of the extracted rubber seed oil was high enough to reach $2.67 \%$ and after the synthesis process decreased the water content to $0.092 \%$ but did not meet ASTM standards. While the density and FFA content of biodiesel have met the standards, the biodiesel density of each catalyst is in the range of 0.8 $\mathrm{g} / \mathrm{cm}^{3}$ and the FFA content is below 2\%. The graph of the comparison of FFA levels before and after the reaction can be seen in Fig. 4. The low FFA levels in the synthesized biodiesel indicate an esterification reaction has been occured and free fatty acids are successfully converted into methyl esters.

To determine the fatty acid composition of the oil and the methyl ester composition formed during the synthesis process, GC-MS analysis was performed. The content of fatty acids and methyl esters in RSO and biodiesel are summarized in Table 4.

Based on the GC-MS analysis data in Table 4, it is known that some of the main fatty acids contained in rubber seed oil are linoleic acid, linolenic acid, palmitic acid, and stearic acid. These fatty acids are then converted into their fatty acid methyl ester (FAME) form during the esterification and transesterification processes. The $\mathrm{ZrO}_{2} / \mathrm{ZAA}$ catalyst showed the best performance in converting the total FFA to FAME up to $86.52 \%$, while the $\mathrm{PbO} / \mathrm{ZAA}$ and $\mathrm{ZnO} / \mathrm{ZAA}$ catalysts reached $39.99 \%$ and $33.58 \%$, respectively. It can be seen that in $\mathrm{PbO} / \mathrm{ZAA}$ and $\mathrm{ZnO} / \mathrm{ZAA}$ there is a number of palmitic acid which is not converted while

Table 3. Characteristics of rubber seed oil (RSO) and biodiesel.

\begin{tabular}{|c|c|c|c|c|c|c|}
\hline \multirow{2}{*}{ Characteristic } & \multirow{2}{*}{$\begin{array}{c}\text { ASTM D6751 } \\
\text { (biodiesel) }\end{array}$} & \multirow{2}{*}{ RSO } & \multicolumn{4}{|c|}{ Biodiesel } \\
\cline { 5 - 8 } & & & ZAA & PbO/ZAA & ZnO/ZAA & ZrO $/$ ZAA \\
\hline Yield (\%) & - & - & 12.061 & 22.670 & 30.860 & 58.104 \\
\hline Water content (\%) & 0.05 & 2.67 & 0.152 & 0.135 & 0.101 & 0.092 \\
\hline FFA $(\%)$ & $<2$ & 3.9 & 2.504 & 1.342 & 1.281 & 1.081 \\
\hline Density $\left(\mathrm{g} / \mathrm{cm}^{3}\right)$ & $0.860-0.900$ & 0.89 & 0.871 & 0.883 & 0.870 & 0.880 \\
\hline
\end{tabular}




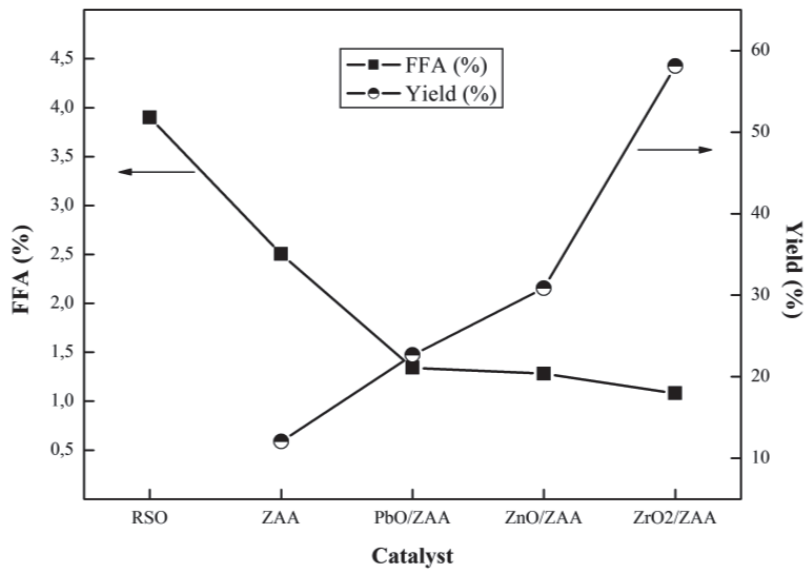

Fig. 4. Graph of yield and FFA reduction in biodiesel. in $\mathrm{ZrO}_{2} / \mathrm{ZAA}$ there is a number of unconverted stearic acid.

There is a significant difference between the conversion results using an acid activation catalyst and a metal oxide embedded catalyst. The difference in the number of conversions with various catalysts is closely related to the ability of the catalyst to convert these compounds seen from the zeolite character and the presence of metal oxides as basic site in zeolite. Metal-bearing zeolites produce a bifunctional catalyst having both of acidic and basic site. So that the metal loaded on zeolite can increase the ability to convert oil into biodiesel. In addition, calcination was also found to be an important factor for the high strength of active site and surface area due to the formation of the active crystal structure [32].

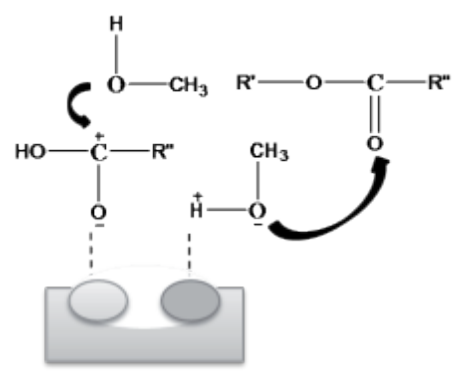

Basic site

Acidic site

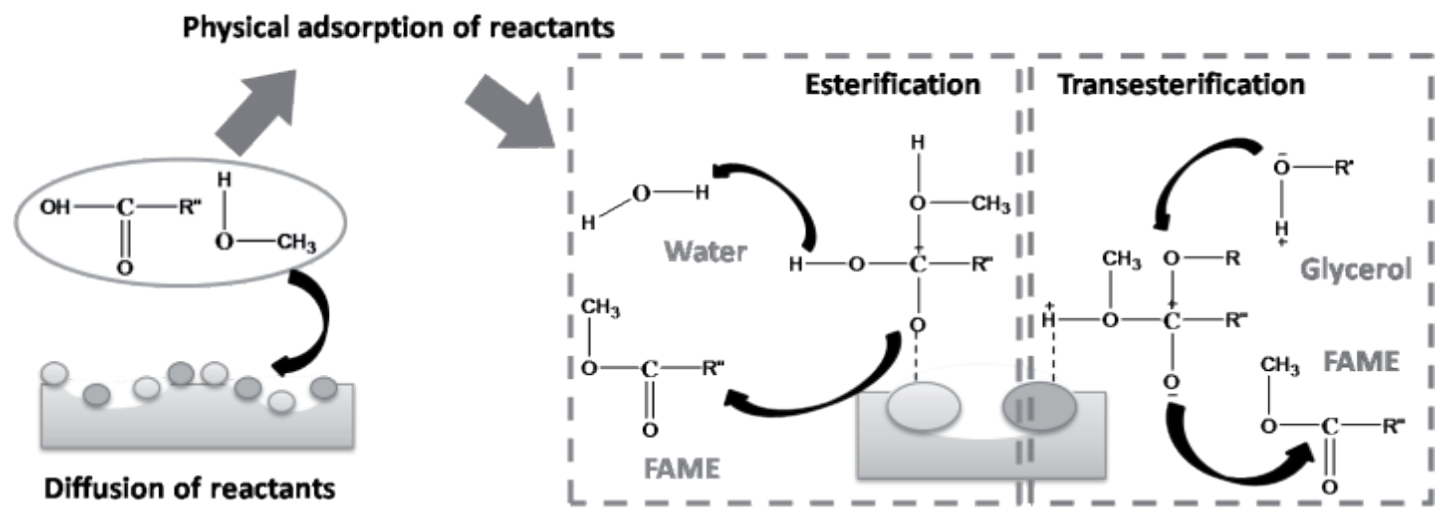

Fig. 5. The reaction mechanism of biodiesel production using both of acidic and basic site catalysts.

Table 4. The content of fatty acids and methyl esters in RSO and biodiesel.

\begin{tabular}{|c|c|c|c|c|c|}
\hline \multirow{2}{*}{ Compound } & \multirow{2}{*}{ Formula } & \multicolumn{3}{|c|}{$\%$ Area } \\
\cline { 4 - 6 } & & RSO & PbO/ZAA & ZnO/ZAA & ZrO $/$ ZAA \\
\hline 9,12-Octadecadienoic acid (linoleate acid) & $\mathrm{C}_{18} \mathrm{H}_{32} \mathrm{O}_{2}$ & 35.44 & - & - & - \\
\hline $9,12,15-$-Octadecatrienoic acid (Linolenate acid) & $\mathrm{C}_{18} \mathrm{H}_{30} \mathrm{O}_{2}$ & 12.10 & - & - & - \\
\hline Hexadecanoic acid (Palmitic acid) & $\mathrm{C}_{16} \mathrm{H}_{32} \mathrm{O}_{2}$ & 14.49 & 0.33 & 0.30 & - \\
\hline Octadecanoic acid (Stearate acid) & $\mathrm{C}_{18} \mathrm{H}_{36} \mathrm{O}_{2}$ & 34.47 & - & - & 8.01 \\
\hline 9,12-Octadecadienoic acid, methyl ester (Methyl linoleate) & $\mathrm{C}_{19} \mathrm{H}_{34} \mathrm{O}_{2}$ & - & 19.86 & 18.44 & 32.86 \\
\hline $9,12,15$-Octadecatrienoic acid, methyl ester (Methyl linolenate) & $\mathrm{C}_{19} \mathrm{H}_{32} \mathrm{O}_{2}$ & - & 0.32 & 0.42 & 12.01 \\
\hline Hexadecanoic acid, methyl ester (Methyl palmitate) & $\mathrm{C}_{17} \mathrm{H}_{34} \mathrm{O}_{2}$ & - & 12.90 & 13.54 & 14.08 \\
\hline Octadecanoic acid, methyl ester (Methyl stearate) & $\mathrm{C}_{19} \mathrm{H}_{38} \mathrm{O}_{2}$ & - & 5.51 & - & 24.25 \\
\hline
\end{tabular}


The possible reaction mechanisms between reactants and bifunctional catalysts based on acidic and basic sites are shown in Fig. 5. Molecular reactants diffuse inside the zeolite pore. Zeolites are embodied metal oxides with Bronsted and Lewis acid sites of active zeolites and basic sites of metal oxides. FFA is adsorbed on the acid site while methanol is adsorbed on the basic site. Protons on the zeolite acid site bind to oxygen in FFA, while metal oxides bind to protons in methanol. The intermediate products are formed by nucleophilic attack of the alcohol into esters at both acidic and basic sites [33, 34]. The hydroxyl is then released in the form of water molecules from the esterification reaction at the acid site while glycerol is formed as by product of the transesterification reaction at basic site [35]. Furthermore, the water and glycerol formed are desorbed from the surface of the catalyst as the final product.

$\mathrm{ZrO} / \mathrm{ZAA}$ catalyst gives the best performance in synthesizing biodiesel compared to ZAA, PbO/ZAA, and $\mathrm{ZnO} / \mathrm{ZAA}$. This is supported by the character of the catalyst which tends to be better based on the results of the analysis and tests that have been carried out. The high crystallinity of the $\mathrm{ZrO}_{2} / \mathrm{ZAA}$ catalyst allows for better thermal stability and structure so that the catalyst is not damaged during the conversion process. Uniform crystal size and cleaner surface morphology facilitate the diffusion of reactants and products during the reaction. The small number of impurities can reduce the possibility of contamination so that the conversion process is more optimal. In addition, catalysts with $\mathrm{Zr}$ metal are reported to have better catalytic activity as heterogeneous acid catalysts in the biodiesel synthesis reaction [36].

\section{Conclusions}

The conversion of rubber seed oil to biodiesel has been carried out using bifunctional catalysts $\mathrm{PbO}$ / $\mathrm{ZAA}, \mathrm{ZnO} / \mathrm{ZAA}$, and $\mathrm{ZrO}_{2} / \mathrm{ZAA}$ through a one-stage esterification/transesterification reaction. The best catalyst performance is shown by $\mathrm{ZrO}_{2} / \mathrm{ZAA}$ which is capable of measuring up to $58.10 \%$. The high FFA content in RSO was successfully converted to MEFA until the levels were reduced by $86.22 \%$. These abilities are closely related to the character of $\mathrm{ZrO}_{2} / \mathrm{ZAA}$ which is better than $\mathrm{PbO} / \mathrm{ZAA}$ and $\mathrm{ZnO} / \mathrm{ZAA}$ catalysts, including high crystallinity reaching $77.12 \%$, uniform surface morphology and small crystall grains. Moreover, this catalyst has a large spesific surface area and a high total pore volume. These results indicate that the activation and modification processes with the addition of metal oxides can increase the character and catalytic activity of the catalyst. In addition, the biodiesel products produced in this study have met ASTM standards for FFA content and biodiesel density. As a whole, these data show a great potential for RSO to be developed as a renewable and environmentally friendly alternative fuels with heterogeneous based catalyst. Therefore, continuous efforts to modify both heterogeneous catalysts and production methods need to be carried out intensively in the future to increase the effectiveness of biodiesel production from rubber seed oil

\section{Acknowledgements}

The author would like to acknowledge the Rector of Universitas Negeri Medan for the financial support provided through the 2020 basic research scheme with grant number No. 0441/UN33/KEP/PPL/2020.

\section{Conflict of Interest}

The authors declare no conflict of interest.

\section{References}

1. ULFAH M., MULYAZMI M., BURMAWI B., PRAPUTRI E., SUNDARI E., FIRDAUS F. Biodiesel production methods of rubber seed oil: A review. IOP Conference Series: Materials Science and Engineering, 334 (1), 2018.

2. CHAMOLA R., KHAN M.F., RAJ A., VERMA M., JAIN S. Response surface methodology based optimization of in situ transesterification of dry algae with methanol, $\mathrm{H}_{2} \mathrm{SO}_{4}$ and $\mathrm{NaOH}$. Fuel, 239 (November 2018), 511, 2019.

3. AHMAD J., YUSUP S., BOKHARI A., KAMIL R.N.M. Study of fuel properties of rubber seed oil based biodiesel. Energy Conversion and Management, 78, 266, 2014.

4. THAIYASUIT P., PIANTHONG K., WORAPUN I. Acid Esterification-Alkaline transesterifi cation process for methyl ester production from crude rubber Seed Oil. Journal of Oleo Science, 61 (2), 81, 2012.

5. ANDREO-MARTÍNEZ P., ORTIZ-MARTÍNEZ V.M., GARCÍA-MARTÍNEZ N., DE LOS RÍOS A.P., HERNÁNDEZ-FERNÁNDEZ F.J., QUESADA-MEDINA J. Production of biodiesel under supercritical conditions: State of the art and bibliometric analysis. Applied Energy, 264 (October 2019), 114753, 2020.

6. SHAKORFOW A.M., MOHAMED A.H. Homogenous Acidic and Basic Catalysts in Biodiesel Synthesis: A Review. Acta Chemica Malaysia, 4 (2), 76, 2020.

7. SINGH D., GANESH, A., MAHAJANI S. Heterogeneous catalysis for biodiesel synthesis and valorization of glycerol. Clean Technologies and Environmental Policy, 17 (4), 1103, 2015.

8. SAHABDHEEN A.B., ARIVARASU A. Synthesis and characterization of reusable heteropoly acid nanoparticles for one step biodiesel production from high acid value waste cooking oil - Performance and emission studies. Materials Today: Proceedings, 22 (xxxx), 383, 2020.

9. SIHOMBING J.L., PULUNGAN A.N., LINDAWATI P., PRAYOGA A., AYU SAFITRI I., NUR WANDANI C., SILITONGA L.A., AMBARWATI., PRAYUGO P., ANGGARA WIBOWO A. Optimization of Indonesia biodiesel production from rubber seed oil using natural zeolite modification. Jurnal Pendidikan Kimia, 10 (2), 387, 2018. 
10. SÁNCHEZ FABA E.M., FERRERO G.O., DIAS J.M., EIMER G.A. Thermo-chemically tuning of active basic sites on nanoarchitectured silica for biodiesel production. Molecular Catalysis, 481 (June), 1, 2020.

11. YUSUFF A.S., OWOLABI J.O. Synthesis and characterization of alumina supported coconut chaff catalyst for biodiesel production from waste frying oil. South African Journal of Chemical Engineering, 30, 42, 2019.

12. SU F., GUO Y. Advancements in solid acid catalysts for biodiesel production. Green Chemistry, 16 (6), 2934, 2014.

13. SAHEL F., SEBIH F., BELLAHOUEL S., BENGUEDDACH A., HAMACHA R. Synthesis and characterization of highly ordered mesoporous nanomaterials Al-MCM-41 and Al-SBA-15 from bentonite as efficient catalysts for the production of biodiesel MELA and EELA. Research on Chemical Intermediates, 46 (1), 133, 2020.

14. LAMBA R., SARKAR S. Synergistic effect of mixed alcohols on esterification of decanoic acid with amberlyst 15 as catalyst. Environmental Progress and Sustainable Energy, 38 (4), 1, 2019.

15. SUKMAWATI P.D. Optimization Of Used Cooking Oil Into Biodiesel With Sulfated Zirconia Zeolit Catalyst. Seminar Nasional Teknik Kimia "Kejuangan" Pengembangan Teknologi Kimia untuk Pengolahan Sumber Daya Alam Indonesia, 1, 2016.

16. SHU Q., GAO J., NAWAZ Z., LIAO Y., WANG D., WANG J. Synthesis of biodiesel from waste vegetable oil with large amounts of free fatty acids using a carbon-based solid acid catalyst. Applied Energy, 87 (8), 2589, 2010.

17. THANGARAJ B., SOLOMON P.R., MUNIYANDI B., RANGANATHAN S., LIN L. Catalysis in biodiesel production - A review. Clean Energy, 3 (1), 2, 2019.

18. RISSO R., FERRAZ P., MEIRELES S., FONSECA I., VITAL J. Highly active Cao catalysts from waste shells of egg, oyster and clam for biodiesel production. Applied Catalysis A: General, 567, 56, 2018.

19. DU L., LI Z., DING S., CHEN C., QU S., YI W., LU J., DING J. Synthesis and characterization of carbon-based $\mathrm{MgO}$ catalysts for biodiesel production from castor oil. Fuel, 258 (June), 116122, 2019.

20. ROSCHAT W., PHEWPHONG S., KHUNCHALEE J., MOONSIN P. Biodiesel production by ethanolysis of palm oil using $\mathrm{SrO}$ as a basic heterogeneous catalyst. Materials Today: Proceedings, 5 (6), 13916, 2018.

21. DUTTA S., JAISWAL K.K., VERMA R., BASAVARAJU D.M., RAMASWAMY A.P. Green synthesis of zinc oxide catalyst under microwave irradiation using banana (Musa spp.) corm (rhizome) extract for biodiesel synthesis from fish waste lipid. Biocatalysis and Agricultural Biotechnology, 22, 101390, 2019.

22. SINGH D., BHOI R., GANESH A., MAHAJANI S. Synthesis of biodiesel from vegetable oil using supported metal oxide catalysts. Energy and Fuels, 28 (4), 2743, 2014.

23. LIU W., LIU X., GU Y., LIU Y., YU Z., LYU Y., TIAN $\mathrm{Y}$. A new composite consisting of $\mathrm{Y}$ zeolite and $\mathrm{ZrO}_{2}$ for fluid catalytic cracking reaction. Composites Part B: Engineering, 200 (July), 2020.
24. ELIAS S., RABIU A.M., OKELEYE B.I., OKUDOH V., OYEKOLA O. Bifunctional heterogeneous catalyst for biodiesel production from waste vegetable oil. Applied Sciences (Switzerland), 10 (9), 2020.

25. SEMWAL S., ARORA A.K., BADONI R.P., TULI D.K. Biodiesel production using heterogeneous catalysts. Bioresource Technology, 102 (3), 2151, 2011.

26. SIHOMBING J.L., GEA S., WIRJOSENTONO B., AGUSNAR H., PULUNGAN A.N., HERLINAWATI H., YUSUF M. Characteristic and Catalytic Performance of Co and Co-Mo Metal Impregnated in Sarulla Natural Zeolite Catalyst for Hydrocracking of MEFA Rubber Seed Oil into Biogasoline Fraction. Catalysts, 10, 121, 2020.

27. GEA S., HARYONO A., ANDRIAYANI A., SIHOMBING J.L., PULUNGAN A.N., NASUTION T., RAHAYU R., HUTAPEA Y.A. The stabilization of liquid smoke through hydrodeoxygenation over nickel catalyst loaded on sarulla natural zeolite. Applied Sciences (Switzerland), 10 (12), 2020.

28. LEE H.V., JUAN J.C., BINTI ABDULLAH N.F., NIZAH MF R., TAUFIQ-YAP Y.H. Heterogeneous base catalysts for edible palm and non-edible Jatropha-based biodiesel production. Chemistry Central Journal, 8 (1), 1, 2014.

29. SRIFA A., FAUNGNAWAKIJ K., ITTHIBENCHAPONG V., VIRIYA-EMPIKUL N., CHARINPANITKUL T., ASSABUMRUNGRAT S. Production of bio-hydrogenated diesel by catalytic hydrotreating of palm oil over $\mathrm{NiMoS}_{2} /$ $\gamma-\mathrm{Al}_{2} \mathrm{O}_{3}$ catalyst. Bioresource Technology, 158, 81, 2014.

30. SONG W., ZHAO C., LERCHER J.A. Importance of size and distribution of $\mathrm{Ni}$ nanoparticles for the hydrodeoxygenation of microalgae oil. Chemistry - A European Journal, 19 (30), 9833, 2013.

31. FANG S., SHI C., JIANG L., LI P., BAI J., CHANG C. Influence of metal $(\mathrm{Fe} / \mathrm{Zn})$ modified ZSM-5 catalysts on product characteristics based on the bench-scale pyrolysis and Py-GC/MS of biomass. International Journal of Energy Research, 44 (7), 5455, 2020.

32. GUPTA J., AGARWAL M., DALAI A.K. An overview on the recent advancements of sustainable heterogeneous catalysts and prominent continuous reactor for biodiesel production. Journal of Industrial and Engineering Chemistry, 88, 58, 2020.

33. RAHMAN N.J.A., RAMLI A., JUMBRI K., UEMURA Y. Tailoring the surface area and the acid-base properties of $\mathrm{ZrO}_{2}$ for biodiesel production from Nannochloropsis sp. Scientific Reports, 9 (1), 1, 2019.

34. WAN OMAR W.N.N., AMIN N.A.S. Biodiesel production from waste cooking oil over alkaline modified zirconia catalyst. Fuel Processing Technology, 92 (12), 2397, 2011.

35. AMINI Z., ILHAM Z., ONG H.C., MAZAHERI H., CHEN W.H. State of the art and prospective of lipasecatalyzed transesterification reaction for biodiesel production. Energy Conversion and Management, 141, 339, 2017.

36. FARUQUE M.O., RAZZAK S.A., HOSSAIN M.M. Application of heterogeneous catalysts for biodiesel production from microalgal oil - a review. Catalysts, 10 (9), 1, 2020) 
